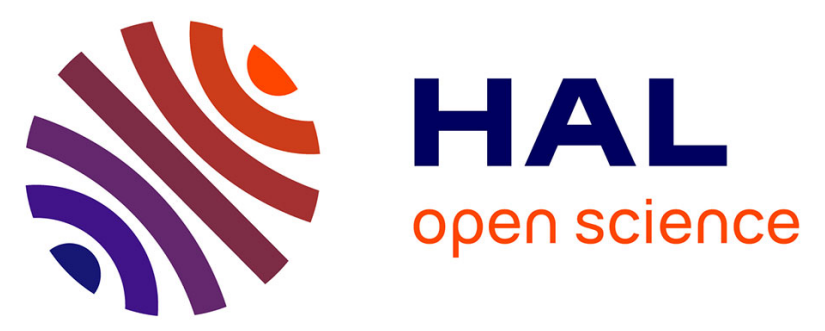

\title{
Damage from the april-may 2015 gorkha earthquake sequence in the Solukhumbu district (Everest region), Nepal
}

David R. Lageson, Monique Fort, Roshan Raj Bhattarai, Mary Hubbard

\section{- To cite this version:}

David R. Lageson, Monique Fort, Roshan Raj Bhattarai, Mary Hubbard. Damage from the april-may 2015 gorkha earthquake sequence in the Solukhumbu district (Everest region), Nepal. GSA Annual Meeting, Sep 2016, Denver, United States. hal-01373311

\section{HAL Id: hal-01373311 \\ https://hal.science/hal-01373311}

Submitted on 28 Sep 2016

HAL is a multi-disciplinary open access archive for the deposit and dissemination of scientific research documents, whether they are published or not. The documents may come from teaching and research institutions in France or abroad, or from public or private research centers.
L'archive ouverte pluridisciplinaire HAL, est destinée au dépôt et à la diffusion de documents scientifiques de niveau recherche, publiés ou non, émanant des établissements d'enseignement et de recherche français ou étrangers, des laboratoires publics ou privés. 
ABSTRACT: Rapid assessments of landslides ice) as well as human impacts were conducted by many organizations immediately following the 25 April 2015 M7.8 Gorkha earthquake and its aftershock sequence. In particular, a NASA-led satellite mapping campaig andslides throughout Nepal, largely concentrated in the "down-dropped northern tectonic block" well north of Kathmandu in the Greater Himalaya (Kargel et al, 2016). The Solukhumbu District lies at the eastern 2015 M7.3 aftershock Given the enormous $12 \mathrm{May}$ and economic value of the Khumbu region to Nepal, we eomorphic and structural damage in the fall of 2015 , nd a third ground assessment of rebuilding efforts in movements were not as extensive as those to the numerous landslides and slumps were identified west mostly on steep, convex-up, east-facing slopes where the dip of metamorphic follation (Namche orthogneiss d where villages were located on terraces of unconsolidated sand and gravel perched above the Dudh Koshi River (Nakchun Village). The area upstream movements on steep slopes that had clearly failed vegetated slump blocks and steep, unstable hummocky Thame northwest of Namche Bazar, constructed of unconsolidated, water-saturated glacial outwash Thame Khola Valley. Aside from Thame, one is struck the randomness of structural damage in many Sherpa Wuages, reflecting micro-ground conditions beneath stacked fieldstone versus the use of mud or cement mortar, the presence of wire mesh or gabion bands/spacers within stone walls, etc.). Fresh valley-
lank slumps and landslides were markedly less obvio further north (towards Everest) where wide glacial ther mass movements in the past is cleorly pls and.

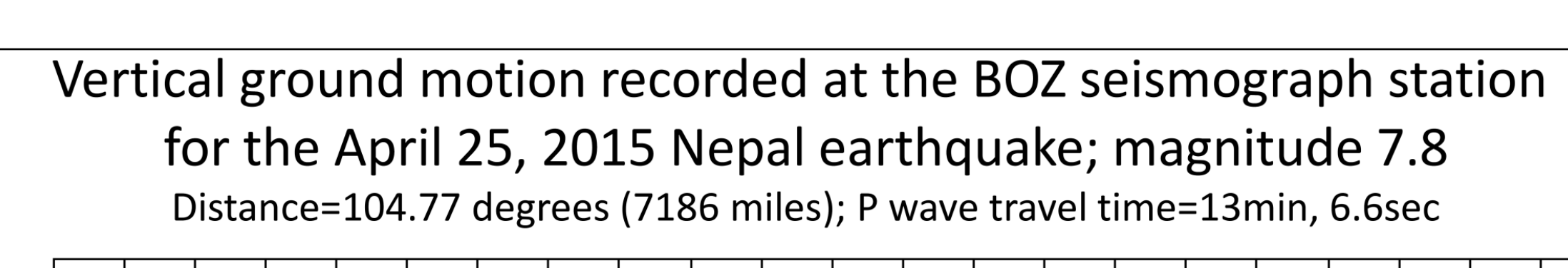

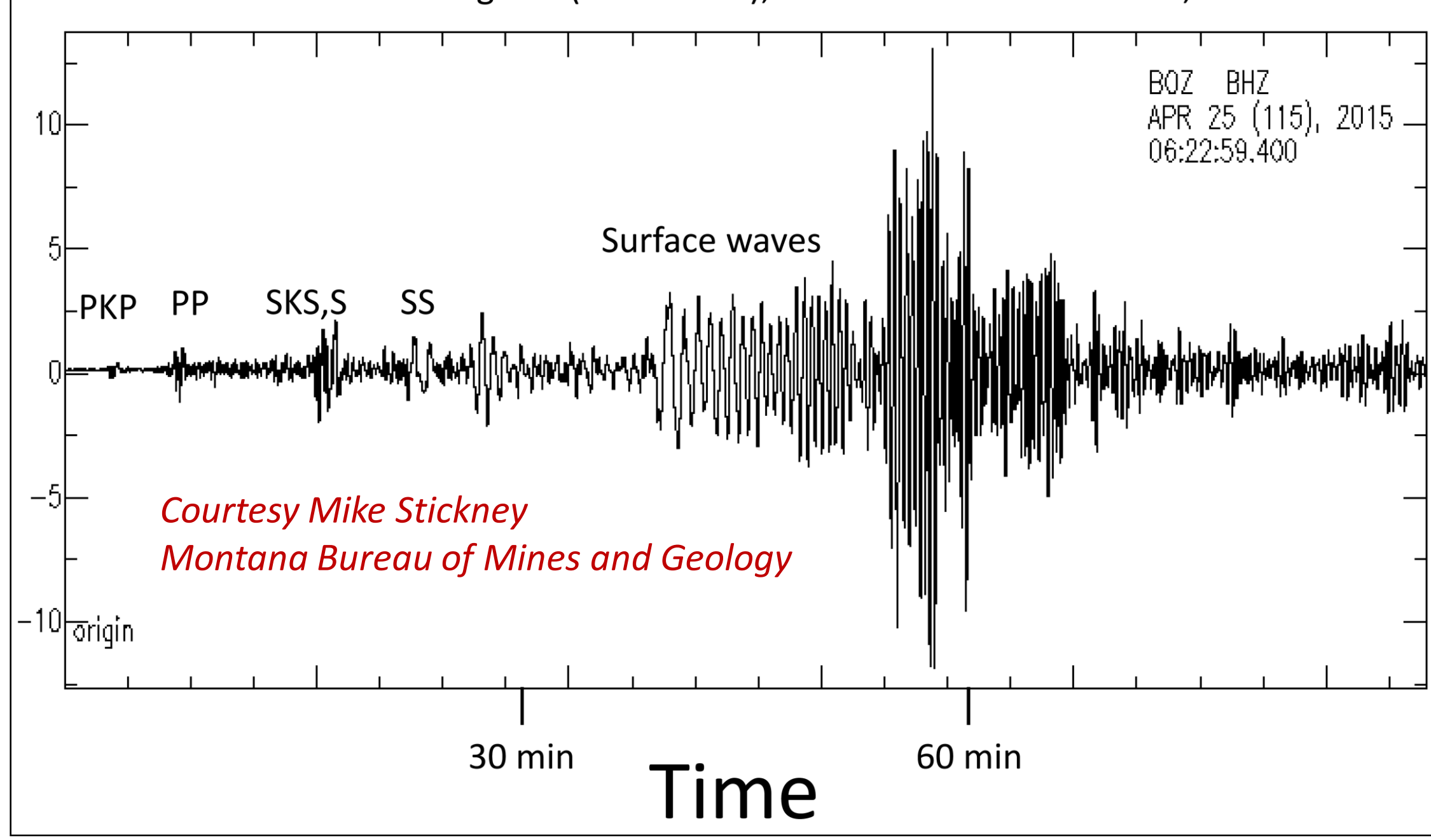

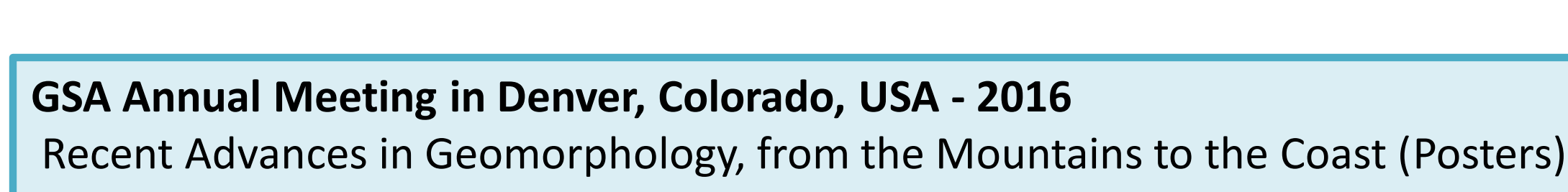

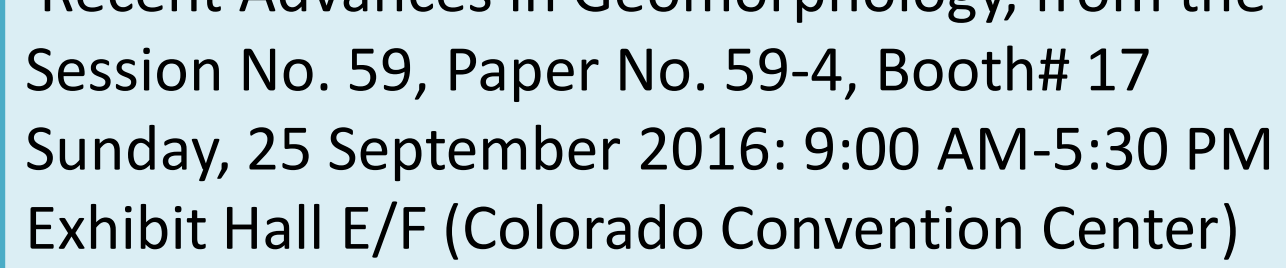

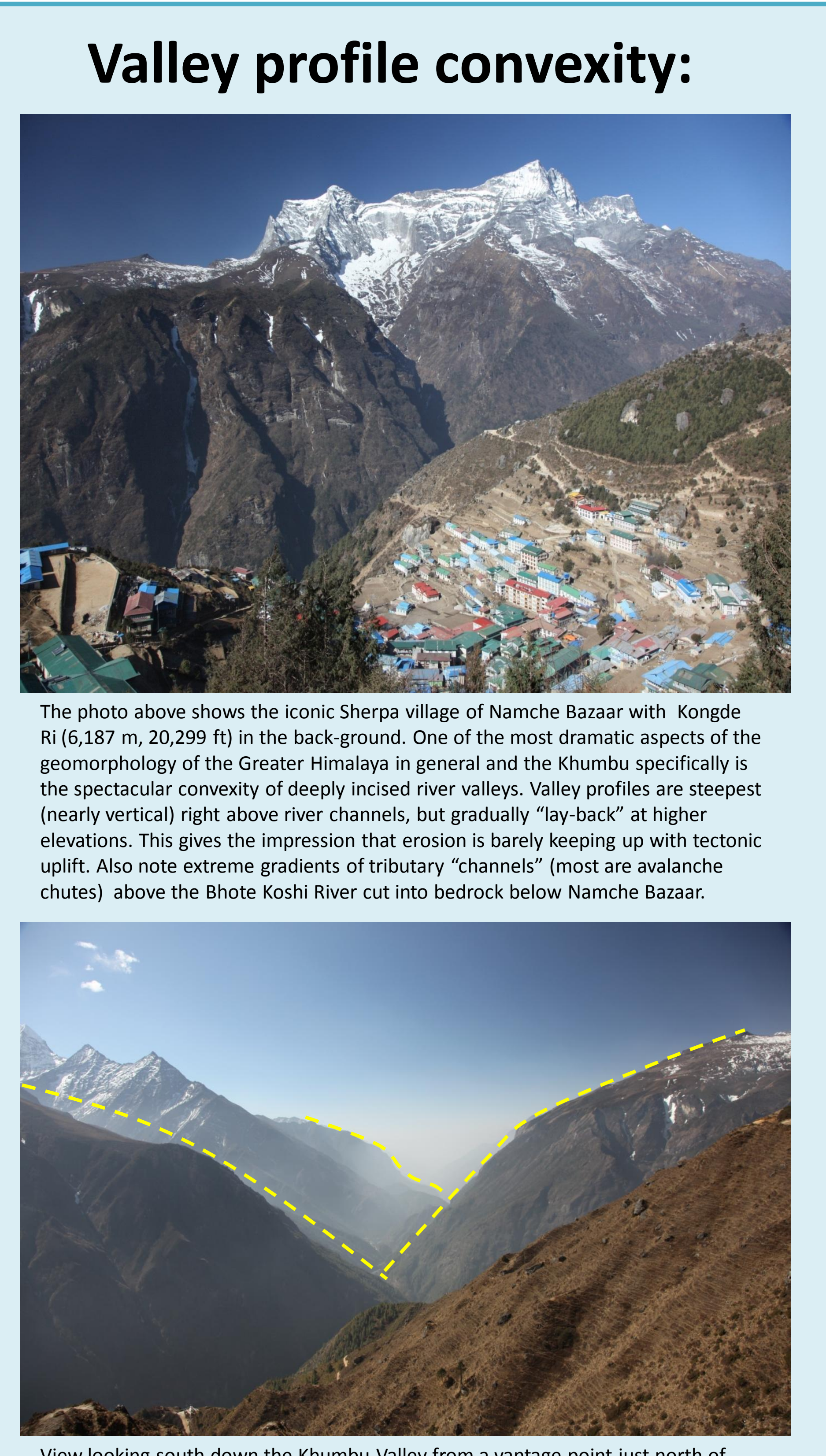

Earthquake-triggered mass movements (past \& recent)
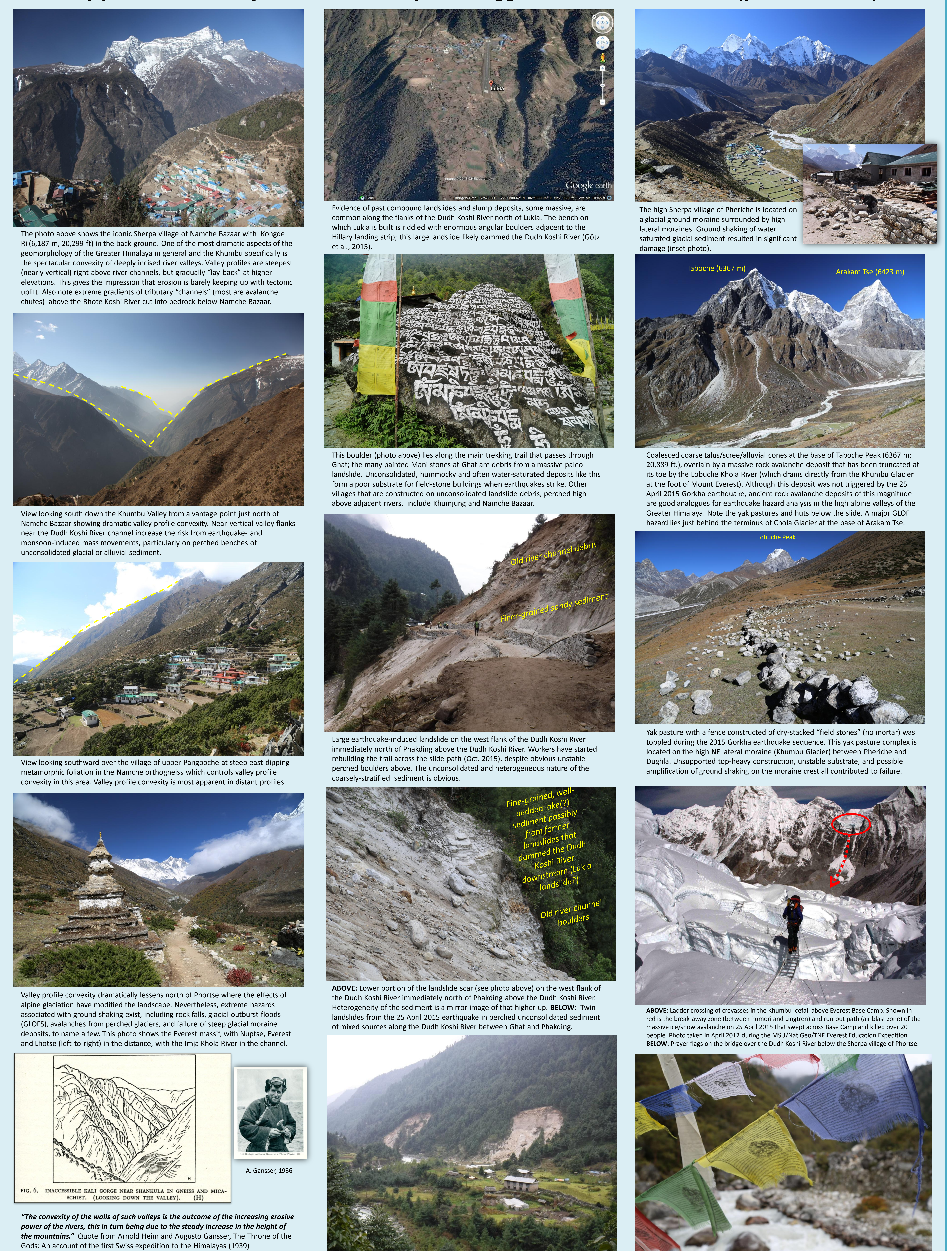

Traditional and new construction methods:

Spectrum of structural damage:
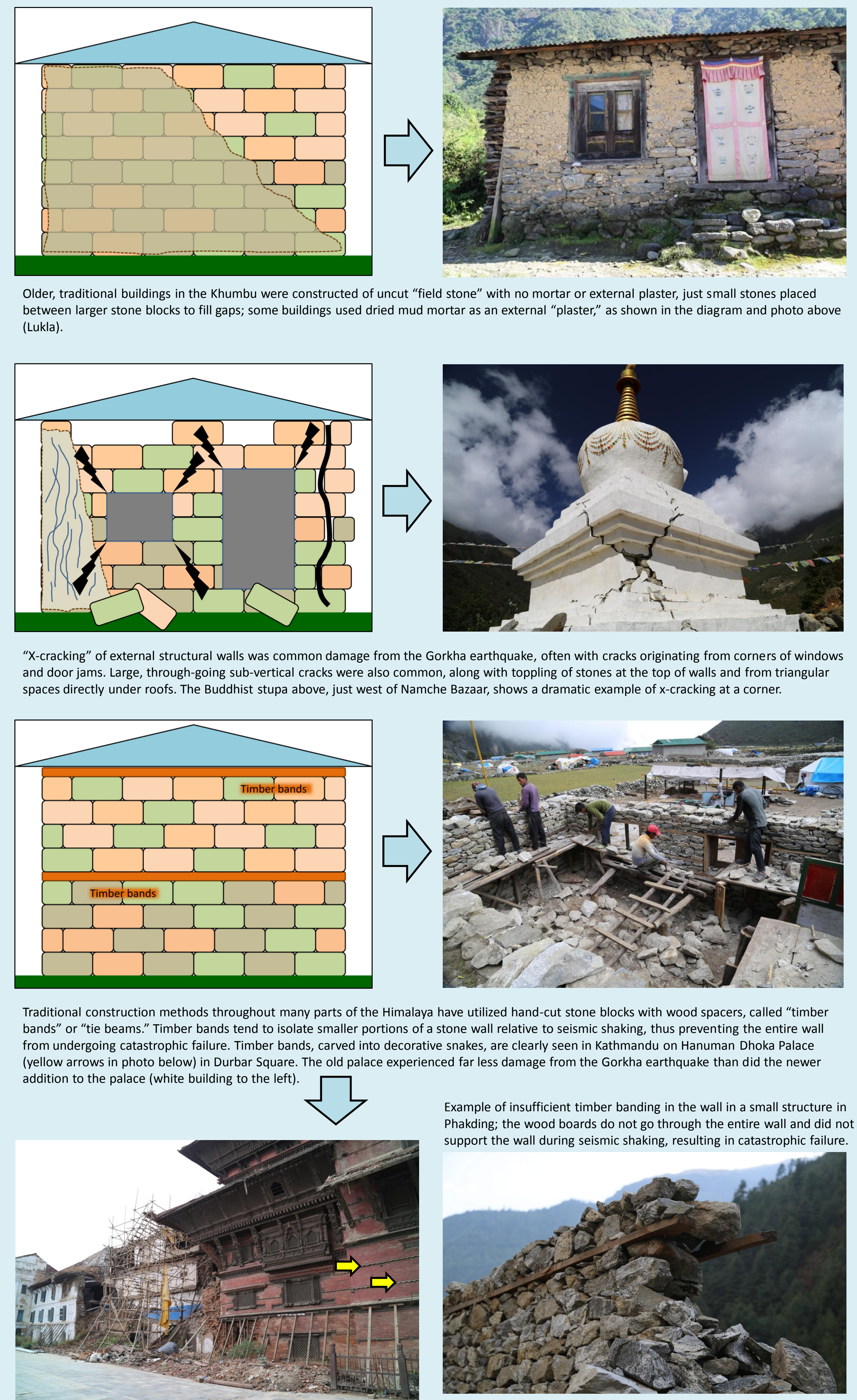

Rebuilding the Khumbu:

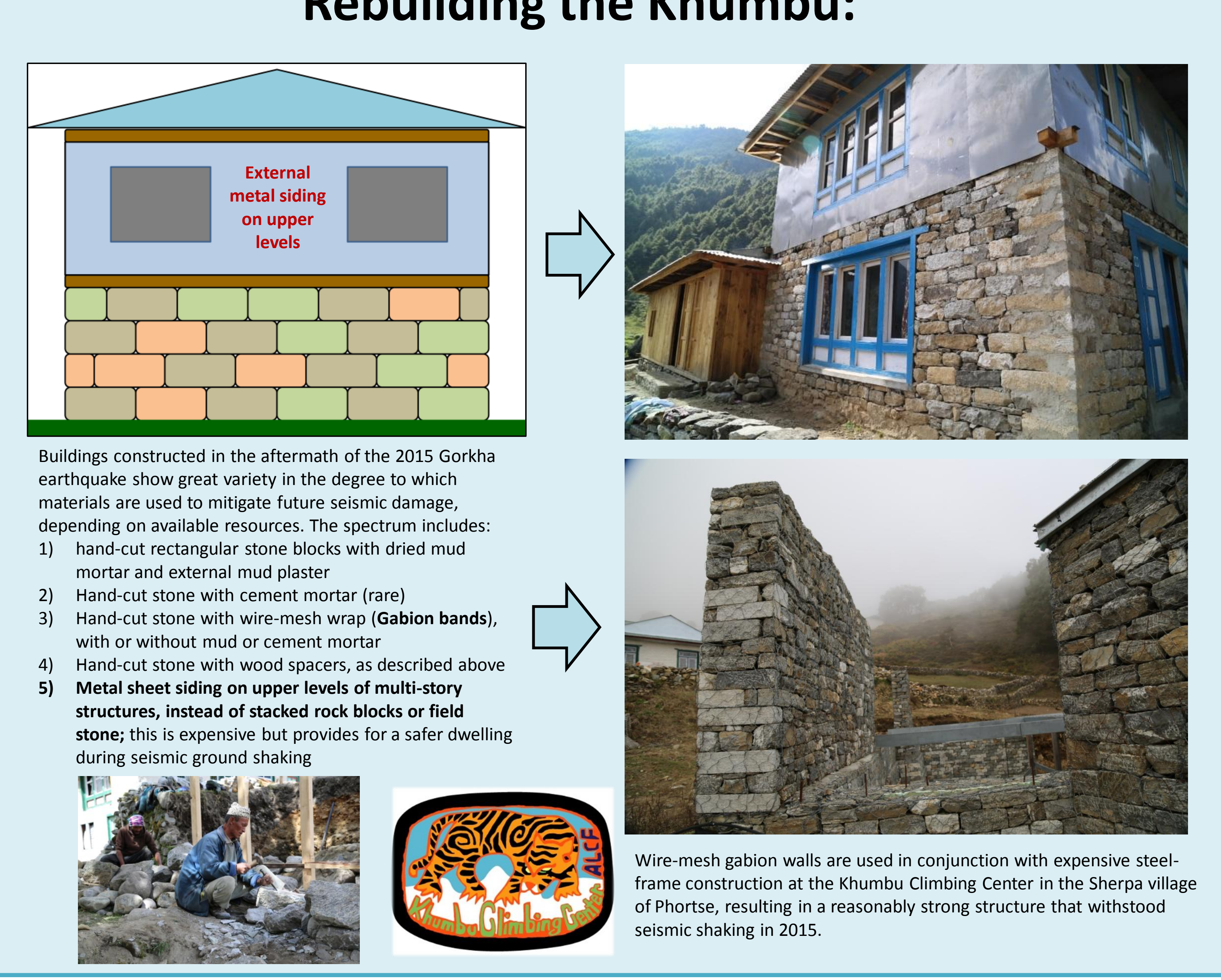

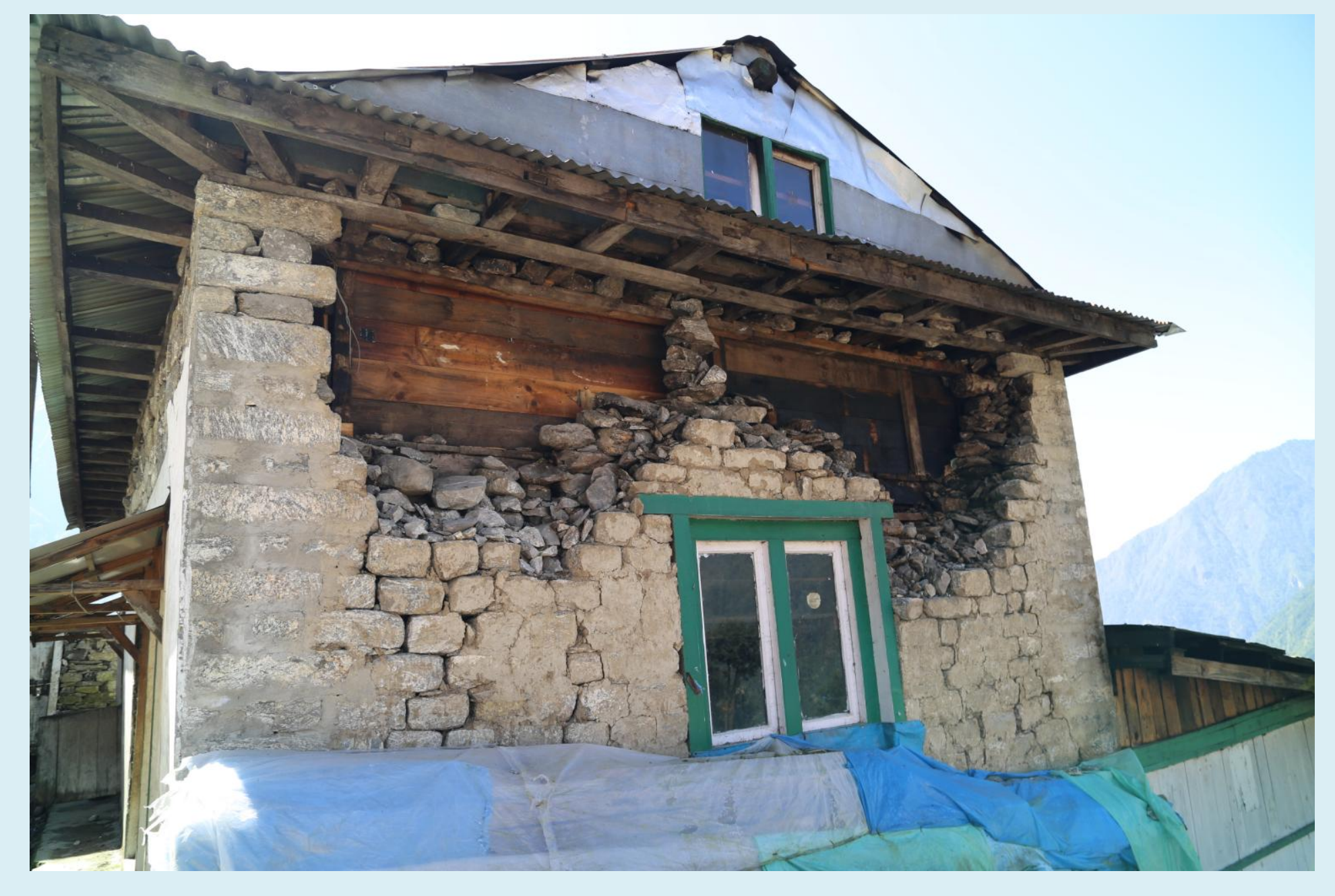
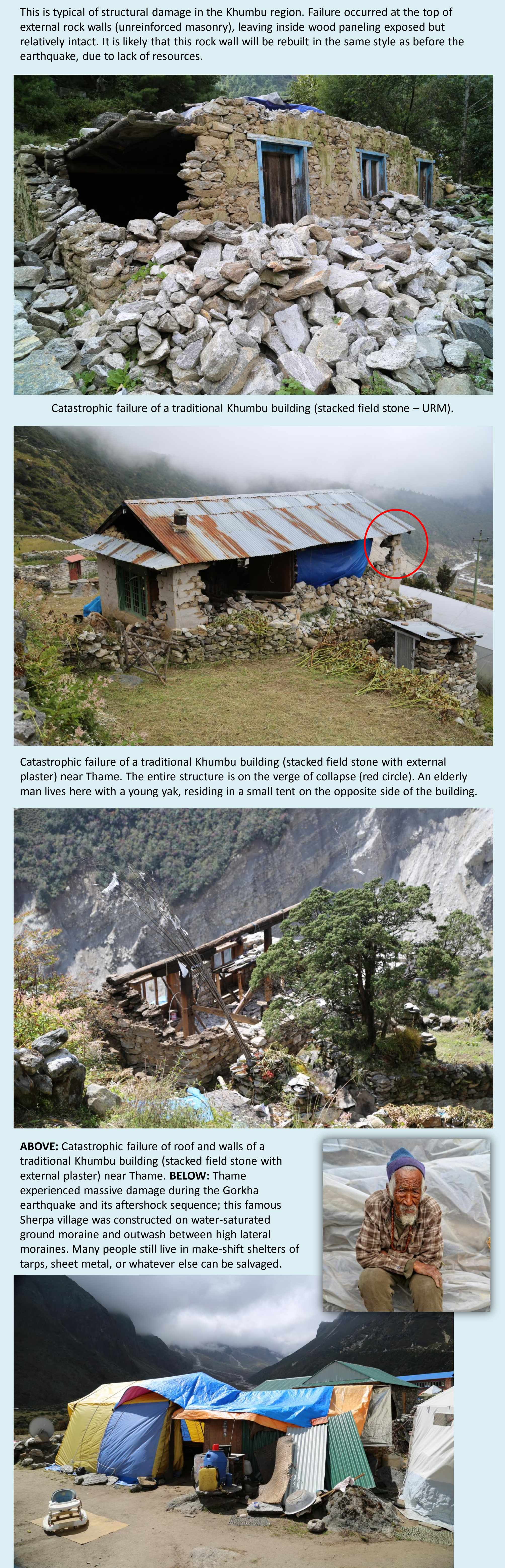